\title{
The Public Good of Internet Usage and its Social Impact: A Business Ethics Approach
}

\author{
Roland Bardy \\ $\mathrm{PhD}$, Executive Professor, Florida Gulf Coast University, Fort Myers, USA
}

\section{Arthur Rubens}

$\mathrm{PhD}$, Professor Emeritus, Florida Gulf Coast University, Fort Myers, USA

\begin{abstract}
Public goods are indispensable for producing value in an economy and their usage is part of resource consumption in by any business. Of the two types of public goods ${ }^{1}$, natural ones and social ones, it has mainly been the natural resources, which caught the attention of politicians, academics and business alike. And it is only the natural public goods like, e.g., air and water, for which attempts have been made to develop monetary valuation. This is changing as the Internet gets into focus. The various concerns taken up increasingly by policy makers on many issues of the Internet lead to a discussion that is increasingly questioning whether Internet provision really is a public good, if it really is for free, how it can be governed, whether Internet provision can be monetized and how this monetization changes the public goods character of the Internet. It is the purpose of this paper to discuss these topics. One outcome that is sought is to define the societal mandate of the parties involved, which would be to create private economic gain and public welfare. This social mandate must encompass the topic of business accountability - otherwise there will be no social effect from including as many users in Internet access as possible or feasible. Developing a society that is inclusive would be one major objective of conducting stakeholder relations in an ethical manner.
\end{abstract}

Keywords: public goods, Internet, social impact, business ethics, accountability, stakeholder relations, monetization, inclusiveness.

JEL Classification: H41, A13, M2, M41.

Cite as: Bardy, R., Rubens, A. (2019). The Public Good of Internet Usage and its Social Impact: A Business Ethics Approach. Business Ethics and Leadership, 3(2), 63-71. http://doi.org/10.21272/bel.3(2).63-71.2019.

(C) The Authors, 2019. This article is published with open access at Sumy State University.

\section{Introduction}

The usage of public goods like air, roads and the natural environment has habitually been regarded to come without cost, and this also applies to the public good of a well working legal system, of an effective labor market and efficient government authorities. This judgement originates with the definition of a public good: "a good that once produced can be consumed by an additional consumer at no additional cost" and "consumers cannot be excluded from consuming the public good once it is produced" (Holcombe 1997: 1). What this judgment has not considered for quite some time is that public goods need to be maintained and preserved, and, where they are underdeveloped, they need to be built up. The cost of this must be borne by each and everyone who uses public goods, be it directly (through fees and excise) or indirectly (through taxes and contributions). With the advent of the Internet, this issue reaches a new dimension: The Internet, at least from how it can be accessed, is certainly some type of public good; Internet usage extends beyond borders; monetization of the Internet affects the balance between individual rights and public good - overall, though, the foremost feature is that it not only promotes innovation and efficiency but social inclusion at all levels (see, e.g., Broeders, 2015). From there, the question arises whether the traditional foundation of public goods can aptly encompass this new phenomenon. By any means, there is a shared role that businesses, governments and individuals play in their communities and beyond.

\footnotetext{
${ }^{1}$ There exists a distinction not only between natural and social, but also between regionally restricted and global public goods. The phenomenon of global public goods is only referred to in the paper as it studies the relevance of the Internet in the "macro-micro- linkage" between governments and business. Other global goods such as climate change mitigation, financial stability, security and global public health remain outside the study. But it is common core that the Internet's nucleus of key protocols and infrastructure can be considered a global public good as it provides benefits to everyone in the world
} 
ISSN (online) - 2520-6311; ISSN (print) - 2520-6761

One major theme is the empowerment approach of Internet usage. The empowerment issue relates to the gap between those who have access to new technologies like computer-aided information and communication skills and those who do not (the "digital divide"). Ever since the development of the Internet, the gap has both widened (from a cross-border perspective; see Herman, 2003) and narrowed (from the perspective of user statistics within a given society; see Deibert and R. Rohozinski, 2011). The narrowing of the gap is undoubtedly due to the role of business which is getting more and more involved in the broader societal and environment context. Before examining the facets of this role, a brief presentation will be given on the way public goods have been defined and researched in academic literature and by public policy makers. This will be followed by reflections on how to valuate public goods in general and, more specifically, the public good of Internet usage. Apart from monetary valuation, to which there are quite a few attempts, policy makers and practitioners will find more relevance of the Internet's value for society in bridging skills and knowledge gaps, i.e. for bridging the digital divide. There are three obstacles, though, for overcoming this gulf: access to the technology, let alone free access is not available to everyone; the tendency towards corporate control of the Internet, the demand of governments to practice Internet surveillance. However, when reflecting on how the discussion about public goods came about, as will be done in the following section, it will emerge that there were always obstacles of this kind. Take the groundbreaking work of Elinor Ostrom who received the Nobel Prize in Economics in 2009 for her work investigating how communities, from medieval time onwards, have manage common resources such as grazing land, forests and irrigation water: There were always barriers because some members of the society had no access to technology, because some larger entities tried to gain control and/or oversee (see, e.g., Ostrom, 1990).

\section{Approaches to the Public Goods Phenomenon}

One approach to public goods that has much relevance for the topic of Internet usage is based on Paul Samuelson's distinction between what he called "private consumption good, like bread, whose total can be parceled out among two or more persons, with one man having a loaf less if another gets a loaf more" and a "public consumption good, like .. national defense, which is provided for each person to enjoy or not, according to his tastes" (Samuelson, 1955: 350). So, a public good is accessible to everyone (there is no excludability) and it can be used jointly (there is no rivalry). Buchanan (1968/1999) suggested a model with several stages of "publicness" where a good can be procured by both a private and a public provider, like a toll road, with "jointness" occurring not only in the consumption but also in the production of a public good. Another aspect is external economies, or "externalities"2: When one user takes an advantage over all the others, this will adversely affect their condition; also, the behavior of one user can have positive effect on the consumption of a certain public good by the others. The example of access to water plays here well, too. Internet usage certainly raises this type of concerns, because Internet provision is produced jointly (including the providers of connection servers and switch nodes), and consumption is definitely occurring jointly. This also has a social resources perspective: The social resources that need to be around for enhancing Internet usage are, among others, a well-functioning education system, civil infrastructure in cities and other communities and a properly working labor market (Bardy and Massaro, 2013: 501/2). The term "social resources" is wider than "social capital", which is often viewed as a set of connections between people and associated norms for communication. This (narrow) definition that was first created by Bourdieu (1983) and has been adopted by the World Bank: "The institutions, relationships, and norms that shape the quality and quantity of a society's social interactions" (World Bank, 1998: 25). A wider view would encompass the overall social and political environment which allows that rules are set up which shape social structures see, e.g., Grootaert, 1998). Social structures are also determined by what comes out from soft skills of communication, from interaction between members of a society assertively in written and verbal forms, from using personal talents, enhancing creativity, self-confidence, self-management, engagement with work, etc. The upcoming of the digital economy has increased networks substantially, and, hence, the inventory of social resources certainly needs an upgrade to include those soft skills. Also, the Internet as a public good, like with a common pasture used by all farmers in a region, without some mechanism for congestion control, this "commons" will be overgrazed, creating congestion that results in delays and outages. These aspects need to be connected to the topic of individual and business accountability, of moral standards and of monetization as well as to the role soft skills play in all those contexts.

\footnotetext{
${ }^{2}$ The term was created by Arthur C. Pigou ("The Economics of Welfare", London 1920), and the modern operability of the concept was first discussed by Ronald Coase ("The Problem of Social Cost". Journal of Law and Economics, 1960, pp. 1-44).
} 
An approach that differs from the economic view is deriving from the debate between jurists over the meaning of property: Other than what Western jurists have held up for a long time on property being the centuries-old concept of a single proprietor owning a piece of land (Ostrom and Hess, 2007), there is a completely opposite picture drawn by the English jurist H. S. Maine. He found that in the primitive Germanic village communities (the "Mark"), it was "more than likely that joint ownership, and not separate ownership is the really archaic institution" (Maine, [1861] 1963: 252). There is more to this than just a historian's find, because the 19th and the early 20th century have seen a political debate over which arrangement should rule common property. In his famous article on 'The Tragedy of the Commons' Hardin (1968) argued that when there are no limits on use of common property, members of a group may take advantage of a shared resource until it is exhausted. This points toward strict regulation. On the other hand, if it can be warranted that there is stable supply and that there are responsible stakeholders who strictly monitor the use of a common resource, this resource could also be provided by private actors and communal organizations. This is an argument set forth by Ostrom in her famous book "Governing the commons: The evolution of institutions for collective action (Ostrom, 1990). Her argumentation has aroused wide discussion. The opponents strictly reject any privatization of public goods if they provide a "vital service" like health (e.g., Fisk, 2000) and education (e.g., Noddings, 2000). Others would allow private public partnerships for these commons if international frameworks are devised for regulating such partnerships (e.g., Robertson and Verger, 2012). New light is shed on these concerns by the discussion about how governments and private business need to collaborate in the provision of Internet usage. The most salient issues in this are accountability and inclusiveness: Both are themes of business ethics. Can managers in businesses and in government entities who feel accountable to their stakeholders improve the performance of Internet usage? Can they at the same time assure that Internet access is widespread, that all users are treated equal and that reasonable quality standards are upheld (see, e.g. Steets, 2004)? Or is publicprivate collaboration overgrown by the increase in state interference with Internet infrastructure (Ziewitz and Brown, 2014)? Before dealing with this, a cursory annotation shall be made on how the public goods phenomenon is reflected in statistics.

\section{Statistical Issues with Public Goods}

Information on public goods on a wider scale has only recently become available in national accounts, as the subject now dominates policy agendas. The OECD has outlined a framework for better integration of economic, environmental and social issues in statistics with its report "Policies to Enhance Sustainable Development" (OECD, 2001). Then there is an expansion of the UN System of National Accounts ("SNA"; United Nations et al., 1993), which is the National Accounting Matrix that includes Environmental Accounts (NAMEA). With regard to social capital/social resources, measurement instruments have started to be discussed in UN, EU and OECD policy documents (Murphy, 2012), and various templates for exhibiting the magnitude of social resources have been developed, e.g., in the U.K (Harper and Kelly, 2003) and in Germany (Dill and Gebhart, 2016). In the end, the outcome would be an inventory of "social resources" for a region or a country, and, optimally, monetary values would be assigned. With the emergence of the digital economy and the exponential growth of networks and cloud computing this inventory will have to include the Internet and other such technological advances. As digitization it is one of the most important aspects that fosters sustainable development, a smooth performance in the Internet is of the essence. It could be said that this is a classic problem in the concept of the 'commons'. Going back to the example of villagers who have joint and unlimited access to a common grazing field: Each villager will graze his cattle in disregard of the disadvantages (or costs) which this imposes on the others. There has to be some mechanism for congestion control, otherwise the commons will be overgrazed. Similarly, with unlimited access to the Internet, there is a tendency to "overgraze", i.e., creating congestion that potentially results in delays and outages. Assigning a monetary value might help here also. It would reveal the magnitude of resources that are provided to the users. One critical issue, though, is which methodology to choose for arriving at monetary values. The role which business is increasingly playing in the context might help here.

\section{Public Goods and the Business Environment}

There is a new role which business has been advised to take on with public goods, and this has been acknowledge by academia as well: In April 2016, AACSB International announced new directions for business education, highlighting five key opportunities for business schools: Business schools (and, consequently, businesses) will act as: "catalysts of innovation, co-creators of knowledge, hubs of life-long learning, leaders in leadership, and enablers of global prosperity" (AACSB, 2016: 4). The fifth vision in particular, acting as an enabler of global prosperity, was expanded to state that business is expected to be an "active participant in 
ISSN (online) - 2520-6311; ISSN (print) - 2520-6761

addressing broad societal goals and social challenges" (AACSB, 2016: 5). This vision is consistent with the changing role for businesses in our global economy and our global society, and the changing role of business and public goods.

From a business perspective, an input (any resource, and this includes public goods) needs to create value. Non-perishable resources that create value are a firm's capital. So, public goods are a part of the capital base for value creation. They are among the five types of capital - natural, social, human, manufactured and financial capital that were identified by various research groups (see, e.g., the Sustainable Livelihoods Framework: DFID, 1999; Sigma Guidelines, 2003). The five types compose the "sustainable capital from where we derive the goods and services we need to improve the quality of our lives (Coulson et al., 2015: 301). This concept has been amplified by the International Integrated Reporting Committee (IIRC), which added Intellectual Capital as the sixth type (Soyka, 2013). But neither institution has set up a measurement framework that would give a monetary value to all five/six types of capital.

On monetization, there are several dimensions that can be exhibited through the example of the Internet: One is the impact of Internet usage and e- business adoption on profitability and value creation of a particular firm), one other is process (and cost) improvements in supply chains. Both types of impact can be measured directly. Then there is the subject of increased stakeholder dialogue where some effects are less direct (as they are, e.g., deploying soft skills), and there is the multifaceted effect of good working provider/customer/government relations on practical solutions in the wide area of property rights, surveillance and legal frameworks. All these topics demonstrate that the Internet, while providing benefits for all users without exclusion and granting access to all users jointly, can be deemed to be a public good. It is not measurable in terms of attributed monetary value like natural resources use like for a firm to be allowed emissions or effluents into the environment. But it definitely delivers economic benefits. So, cost-benefit analysis could help with monetization.

\section{Public Goods Valuation with Cost-benefit Analyses?}

Publicness of a good implies that there is only a loose connection or no connection at all between what an individual contributes and the benefits reaped. In the case of a wholly private good, the user "gets what he pays for". When a good is public, its production or reproduction is not directly or not at all procured by the beneficiary. This holds true where the public good is fully non-excludable, i.e. no one can be prevented from making use of it, and where it is non-depletable, i.e. all parties can make use of it without any one's consumption of the good being diminished. But with the many interrelations within an economy, there will always occur cases when exclusion and depletion may occur. If we take water management, the need for introducing controls becomes evident when shortages happen. It was water management, then, in the 1950s, where benefit-cost analysis was first used to determine which decisions about the common good of water resources have to be made (Brouwer and Pearce, 2005). Since then the methodology of benefit-cost have been refined, and the problems being dealt with have changed significantly. With regard to natural capital, issues like the recognition of recreational and visual amenities, the preservation of unique ecological habitats and endangered species have been enhanced (Freeman, Herriges and Cling, 2014: 3). In the social sphere, we have new patterns of cooperation, transnational networks, cross-national ties, societal inclusion, inclusive organizations and inclusive business approaches, with digital inclusion being one of the primary concerns both at the business and the macro levels (for a broader discussion see, e.g., Fuchs, 2007). This brings us back to the notion of the many intermediate stages between public and private in the provision of Internet services. The discussions that are held in all circles are about data ownership, Internet governance, power imbalance, hazard prevention and much more. All of this concerns the cost-benefit paradigm. Ownership, governance, power imbalance, hazards are issues that relate to all types of public goods. But digitization has changed the way to access those issues as it has also changed the economic potential of businesses and the patterns of economic competition on markets.

There are four aspects of market digitization, and each on affects how cost and benefit of Internet usage are demarcated: The collection, processing and commercial use of data by big business changes the interplay between data, market power and public authorities, above all those that watch over competition (Schepp and Wambach, 2016); from that end, unhindered access to data is often blocked by the enormous transaction costs. The transaction cost conception gets new relevance (the cost for data centers, for building a sufficiently large customer base to offset huge investments in these centers and for exhaustive data analysis). On the other hand, Internet usage increases transparency between suppliers and customers, and it generates new types of task 
sharing that in generate new types of benefits, such as, e.g., reduced information asymmetries between consumers and suppliers. Thirdly, prices may lose their relevance when competition is at work on non-price factors like data and network accessibility. This also produces indirect network effects, i.e. the use of a good or service by a user directly or indirectly impacts the value of that product or service to other users (Budzinski and Stöhr, 2018). Last, not least, with all sorts of Internet users accessing a firm (and saving the firm time and money in, e.g., order processing), labor (and labor cost) is no longer confined to what is expensed for the people who are on the payroll of the firm. This is one aspect the so called clickworkers-phenomenon, and it is the one that relates to the topic of cost-benefit. Other perspectives that are often discussed are the sometimes questionable/destructive work and employment structures when firms are contracting out, etc., (see, e.g., Sharma, 2017). They are outside the scope of this study.

New types of market structure and the wider definition of transaction cost, mutual network effects and the click-worker issue require adjustments in valuating efforts for the public good of Internet provision. One more angle that relates to cost-benefit in digital relations is that whoever accesses the Internet contributes to this public good with costs and benefits. For this, the term produsage has been coined (Bruns, 2008), How much produsers benefit and how much they expense - that is, the specific balance between usage and produsage which results - remains a matter of individual choice for each participant, subject to their specific personal cost-benefit calculations (Bruns, 2012). So, the methodology of valuating Internet usage will depend on which are the digitization activities of which a firm deems that they produce a cost, and which are those that it deems to produce a benefit. We may, thus, classify the Internet to be one public good that can be monetarized and can become part of the capital base for determining the sustainable value added created by a private enterprise. And there are certainly cost that can be measured, and there are benefits, that can be measured.

For the sake of completeness, here is a short summary of the other methods to valuate public goods:

The general approach is based on what a good/a resource contributes to human welfare, compared with the contribution of other assets, and some type of economic value is sought for those resources, which provide substantially to human welfare. Examples are clean air and ecological services, like, e.g. flood and wood fire prevention. Even though they have no "market" on their own, they are indispensable "inputs" for the production of marketable goods and services. So, monetary terms can be derived for assigning a value to those inputs. In the age of the Internet, though, "money" is not all that counts. "Monetization" of internet provision is through acquisition of data. This may turn upside down what has so far been developed in public goods valuation. Still, two methods will remain valid, at least in part, even though they have almost exclusively been used to valuate environmental goods. One technique is to determine which preference is given to distinct changes in the state of the environment ("contingency valuation"); another method attempts to determine a cost for what the natural environment contributes to agricultural production ("rent capitalization").

\section{Contingency Valuation}

Contingency valuation (CV) is based on surveys. A CV survey asks for preferences concerning alternative actions which a public authority might choose, e.g., for widening a road or maintaining the present width in favor of a children's playground: "What would you be willing to pay for this or that alternative?" So, a hypothetical market is created by the survey, and an economic value is attached to the alternatives. The main critiques to this method are that it introduces passive use into economic analysis and that survey-based methods are to some extent arbitrary (Venkatachalam, 2004).

\section{Rent Capitalization}

The method of rent capitalization supposes that there are different rents/benefits obtained from different uses of a public good. A forest, for example, can be used to provide wood and fiber or it can be used for amenities like hiking and wildlife observation. If cash equivalents can be found for all the services the good may render, these "rents" can be capitalized into monetary values. Rent-capitalization has found its critics who argue this is not more than than simulating a market for an asset, for which an actual market does not exist (Deng, 2003). But, for quite a few public goods, like rivers, roads and infrastructure, monetary quantification cannot be assessed in any other way. And the method certainly works for new types of public goods or "open institutions" that are emerging, like open source software and open science and, also, open public spaces in cities (Von Krogh and Spaeth, 2007). However, the method is not appropriate for valuating of Internet provision, even if cash equivalents could be determined for Internet usage, because there is a social value in play as will be set forth in the next section. 


\section{Assessing the Value of Internet Provision}

Technically, the Internet is a set of multiple networks, which employs packet-switching communications technologies that employ multiplexing: other than in voice telephony switching, where the caller and the called number are connected through a distinct path ("end-to-end setup"), there is no direct connection in the multiplex set between the provider of an information packet and its destination. Each such packet goes to its destination through a series of switches independently. This is very similar to the postal service: The envelope (packet) sent off by a sender is routed through several postal stations, and each of these stations determines where to send the envelope. No end-to-end pipeline is determined from the onset (Krol, 1992: 20-23). This mere technicality makes the point: The existence of an uncongested network is a public good that provides benefits for all users without exclusion; John's use doesn't preclude Mary's use (MacKie-Mason and Varian, 1995). The reference quoted here is from 1995, and the source asks the question how to finance this public good: "The other important task for government is to estimate the public benefit from access and usage by users who might not be willing to pay their own costs, and then to design subsidies to encourage those users"... "We think the growth and development of the Internet will be best served if network services are priced according to cost ... and subsidies should be distributed so that users can pay those charges" (MacKie-Mason and Varian, 1995: 32). However, more than twenty years later, charging for network services is unimaginable. Even though, they are not free - they are paid for by data. This mode of monetizing the Internet raises several concerns: Who should regulate Internet content, and how? What are the responsibilities of an institution/a business toward one of its telecommuters in another country? Should there be a property regime of the digital economy and how would it have to be designed? Can the international character of the Internet be reconciled with the laws of individual nations and the moral standards of individual communities?

Each of the answers to these questions would also relate to the issue of connecting business performance to Internet usage. There are several dimensions: One is the impact of ICT usage and e-business adoption on profitability and value creation of a particular firm (see, e.g., Wu, Mahajan and Balasubramanian, 2003; Levenburg, 2005), one other is process (and cost) improvements in supply chains (see, e.g., McCormack and Johnson, 2016). Both types of impact can be measured directly. Then there is the subject of increased stakeholder dialogue where some effects are less direct and of which skeptics may argue that the internet is rather used by a firm to manage the stakeholder relation (Unerman and Bennett, 2004). And, last not least, there is the multifaceted effect of good working provider/customer/government relations on practical solutions in the wide area of property rights, surveillance and legal frameworks. All these topics demonstrate that the Internet, while providing benefits for all users without exclusion and granting access to all users jointly, cannot be deemed to be a pure public good. It is not measurable in terms an attributed monetary value like the natural resources and the other social resources in the equations presented above. But it definitely delivers economic benefits, both tangible and intangible. So, were back to where we were: Applying cost-benefit analysis seems to be the best avenue. It would also entail an approach to assess what may be called the social value of the Internet.

Social value, according to Sheth et al. (1991), is "the perceived utility acquired from an alternative's association with one or more specific social groups" (Sheth et al., 1991: 161) The term alternative in this definition comes from Sheth's consumption theory, which studies customer choice behavior, i.e., the reason why a customer decides to acquire on of various offerings ${ }^{3}$. There is a social value in all shared resources. Some are obvious, like in the case of the aforementioned open spaces in cities, and some are less so, but it is evident that a society heavily depends on shared infrastructure (Frischmann, 2012). As the Internet has become crucial for societal life, it goes without saying that the question of open access has also become crucial. So, in cost-benefit considerations, finding the appropriate mix between openness and proprietary restrictions is crucial as well. The approach would have to come from both ends: If all systems that are not entirely open would be forbidden, this would dramatically reduce investment in Internet infrastructure and thus Internet functionality. User comfort would fall apart. And if all systems would be entirely open, this would discourage developers of new systems, and, in the end, damage user comfort would be reduced as well. A parallel can be drawn here to cable television: For some time, it was found, the existence of cable's closed platform has led to better equipment standards being developed which then enabled more competitive access for all manufacturers with the consequential benefit for consumers (Hazlett and Bittlingmayer, 2003). So, social gains are always related to cost, as are social benefits. There is room for extensive research into this matter, but it

\footnotetext{
${ }^{3}$ Social value, in this context, is one of five consumption values, with the others being the functional, the epistemic, the emotional and the conditional values. It would be most appealing to connect all the five values to Internet usage. This paper, though, as its focus is on the Public Goods character of the Internet, will confine the analysis to the social component.
} 
requires analysis that involves consideration both within the realm of conventional economic transactions and beyond.

\section{Conclusion}

For a firm to create value for all stakeholders, it has to make use of outside capital tied up in economic, ecological and social resources. The Internet is part of them, and while it is reshaping the patterns of public goods provision, all who participate in digital networks need to earn the cost of Internet usage like all other public goods usage. There is a distinct macro-micro link in this, and with the ever-increasing Internet usage a societal consensus has developed that sees private individuals, businesses and governments in one boat: For one, businesses should not act as agents of their shareholders alone, but they should look to the interests of a wider group of stakeholders. Businesses are more and more recognizing their greater role in society and they also acknowledge that they have wider responsibilities go beyond their immediate shareholders towards a greater stakeholder model. The communal use of the Internet will force corporations to conduct business in a manner that provides social value (like ecological value) to a broad range of stakeholders, while achieving greater long-term performance.

The use of the Internet is creating what can be called an inclusive society, first in those parts of the world where the number of users proliferates. Then, from there a contagion is very likely to happen to the other parts. The role of businesses is to act as inclusive organizations: Inclusive organizations are open systems of opportunity in which all stakeholders have access to information, resources, and the capacity to fully contribute to their functioning. Inclusive organizations not only recognize the value of their internal resources, but also the external that have contributed to their success. In understanding this, business organizations, both public and private must appreciate the role that others have played in gaining success. User skills can only spread throughout the groups that participate in the Internet with this interdependence. A private Internet user who connects to a business firm provides some sort of support to the firm, be it through establishing a new business relation or just by sharing data (willingly or not; but, in the end, anyone user is a priori accepting that data will be shared). This insight will potentially assist in bridging a rift that could develop in a society that differentiates between those who seem to only contribute and those who benefit.

There is no doubt that, in its entirety, Internet provision and Internet use are a very powerful public good. In order to maintain this power, responsible attitudes are needed on all sides and on all levels: Responsible system builders need to provide appropriate technology and access, responsible users need to safeguard the Internet against malpractice, public authorities need to provide prudent guidance. As with all other public goods, there is a cost for build up, for maintenance and preservation and for the efforts to avoid depletion. The foremost item that this cost must warrant is availability - this will ensure growth and well-being in all societies everywhere.

\section{References}

1. AACSB (2016). AACSB Announces Collective Vision for the Future of Business Education. Retrieved from: https://www.aacsb.edu/newsroom/2016/4/aacsb-announces-collective-vision-for-the-future-busineseducation.

2. Bardy, R., and Massaro, M. (2013). Shifting the paradigm of return on investment: a composite index to measure overall corporate performance. Corporate Governance, 13(5), 498-510.

3. Broeders, D. (2015). The public core of the internet. An international Agenda for Internet Governance. The Netherlands Scientific Council for Government Policy. Amsterdam: University Press.

4. Brouwer, R., and Pearce, D. (2005). Cost-benefit analysis and water resources management. Edward Elgar Publishing.

5. Bruns, A. (2012). Reconciling community and commerce? Collaboration between produsage communities and commercial operators. Information. Communication and Society, 15(6), 815-835.

6. Bruns, A. (2008). Blogs, Wikipedia, Second Life and Beyond: From Production to Produsage. New York: Peter Lang.

7. Buchanan, J.M. (1968/1999). The Demand and Supply of Public Goods, The Collected Works of James M. Buchanan, Vol. 5. Indianapolis: Liberty Fund Inc.

8. Budzinski, O., and Stöhr, A. (2018). Competition policy reform in Europe and Germany - Institutional change in the light of digitization. Ilmenau Economics Discussion Papers, No. 117. Ilmenau, Germany: Technische Universität. 
Business Ethics and Leadership, Volume 3, Issue 2, 2019

ISSN (online) - 2520-6311; ISSN (print) - 2520-6761

9. Coulson, A. B., Adams, C. A., Nugent, M. N., and Haynes, K. (2015). Exploring metaphors of capitals and the framing of multiple capitals: Challenges and opportunities for $<\mathrm{IR}>$. Sustainability Accounting, Management and Policy Journal, 6(3), 290-314.

10.Deibert, R. and Rohozinski, R. (2011). Liberation versus Control: The Future of Cyberspace. Journal of Democracy, 21(4), 43-57.

11.Deng, F. F. (2003). Collective goods and the political hold-up problem. Journal of Institutional and Theoretical Economics, 159(2), 414-434.

12.DFID (Department for International Development, 1999). Sustainable Livelihoods Guidance Sheets. London: Department for International Development.

13.Dill, A., and Gebhart, N. (2016). Redundancy, Unilateralism and Bias beyond GDP-results of a Global Index Benchmark. MPRA Paper 74268. Munich: Munich Personal RePEc Archive.

14.Fisk, M. (2000). Surviving with dignity in a global economy: the battle for public goods. Anton, A., Fisk, M., and Holmstrom, N. (eds.), Not for sale: In defense of public goods. Boulder, Colorado: Westview Press, pp. 41-63.

15.Freeman, A.M., Herriges, J.A., and Cling, K. L. (2014). The Measurement of Environmental and Resource Values. Theory and Methods, $3^{\text {rd }}$ edition. Washington, DC: Resources for the Future Press.

16.Frischmann, B. M. (2012). Infrastructure: The social value of shared resources. Oxford University Press.

17.Fuchs, C. (2007). Internet and society: Social theory in the information age. NY: Routledge.

18.Grootaert, C. (1998). Social Capital: The Missing Link? The World Bank Social Capital Initiative, Working Book \# 3. Washington, D.C.: The World Bank.

19.Hardin, G. (1968). The tragedy of the commons. Science, 162, 1243-1248.

20.Harper, R., and Kelly, M. (2003). Measuring Social Capital in the United Kingdom. (U.K.) Office for National Statistics.

21.Hazlett, T. W., \& Bittlingmayer, G. (2003). The political economy of cable open access. Stanford Technology Law Review, 7(1), 4-18.

22.Herman, C. (2003). Becoming Digital: Empowerment, Identity and Community ICTs. Mortberg, C., Elovaara, P. and Lundgren, A. (eds.), How do we make a difference? Information Technology, Transnational Democracy and Gender. Lulea, Sweden: Lulea University of Technology, pp. 237-250.

23.Holcombe, R. G. (1997). A theory of the theory of public goods. The Review of Austrian Economics, $10(1), 1-22$.

24.Krol, E. (1992). The Whole Internet. O’Reilly and Associates, Inc., Sebastopol, CA.

25.Levenburg, N. M. (2005). Delivering customer value online: Practices, applications, and performance. Journal of Retailing and Consumer Services, 12(5), 319-331.

26.MacKie-Mason, J.K., and Varian, H.R. (1995). Pricing the internet. Kahin, B., and Keller, J.H. (eds.), Public access to the Internet: Harvard: MIT Press, pp. 269-314.

27.Maine, Henry Sumner (1963). Ancient Law: Its Connection with the Early History of Society and its Relation to Modern Ideas; With Introduction and Notes by Frederick Pollack, Boston: Beacon Press (reprint of 1861 ed.).

28.McCormack, K. P., and Johnson, W. C. (2016). Supply chain networks and business process orientation: advanced strategies and best practices. Boca Raton: CRC Press.

29.Murphy, K. (2012). The social pillar of sustainable development: a literature review and framework for policy analysis. Sustainability: Science, Practice, and Policy, 8(1), 15-29.

30.Noddings, N. (2000). Education as a Public Good. Anton, A., Fisk, M., and Holmstrom, N. (eds.), Not for sale: In defense of public goods. Boulder, Colorado: Westview Press, pp. 279-293.

31.OECD (2001). Policies to enhance sustainable development. Paris: OECD Publishing.

32.Ostrom, E. and Hess, C. (2007). Private and Common Property Rights. Available at: http://dx.doi.org/10.2139/ssrn.1304699.

33.Ostrom, E. (1990). Governing the commons: The evolution of institutions for collective action. Cambridge: Cambridge University Press.

34.Robertson, S. L., and Verger, A. (2012). Governing education through public private partnerships. Ginsburg, M., Robertson, S., Mundy, K., Verger, A., and Menashy, F. (eds.). Public private partnerships in education: New actors and modes of governance in a globalising world. Cheltenham, UK: Edward Elgar, pp. 21-42.

35.Samuelson, P. A. (1995). Diagrammatic exposition of a theory of public expenditure. The Review of Economics and Statistics, 37(4), 350-356.

36.Samuelson, P. A. (1954). The pure theory of public expenditure. The review of economics and statistics, 36(4), 387-389. 
37.Schepp, N.P., and Wambach, A. (2016). On Big Data and its Relevance for Market Power Assessment. Journal of European Competition Law and Practice, 7(2), 121-129.

38.Sharma, A. (2017). Digitalisation in the UK Service Industries. Vienna: ZSI Centre for Social Innovation.

39.Sheth, J.N., Newman, B.I., and Gross, B. (1991). Why we buy what we buy: a theory of consumption values. Journal of Business Research, 22(2), 159-170.

40.Sigma Guidelines (2003). Putting Sustainable Development into Practice - A Guide for Organisations. London: British Standards Institution (BSI).

41.Soyka, P. A. (2013). The International Integrated Reporting Council (IIRC) integrated reporting framework: toward better sustainability reporting and (way) beyond. Environmental Quality Management, 23(2), 1-14.

42.Steets, J. (2004). Developing a framework: Concepts and research priorities for partnership accountability. Global Public Policy Institute Research Book Series, No. 1. Berlin: Global Public Policy Institute.

43.Unerman, J., and Bennett, M. (2004). Increased stakeholder dialogue and the internet: towards greater corporate accountability or reinforcing capitalist hegemony? Accounting, Organizations and Society, 29(7), 685-707.

44.United Nations, International Monetary Fund, Commission of the European Communities-Eurostat, Organisation for Economic Co-operation and Development, World Bank (1993). System of National Accounts 1993, New York: United Nations.

45.Von Krogh, G., and Spaeth, S. (2007). The open source software phenomenon: Characteristics that promote research. The Journal of Strategic Information Systems, 16(3), 236-253.

46.World Bank Social Capital Initiative (1998). The initiative on defining, monitoring and measuring social capital: overview and program description. Social Capital Initiative Working Paper no. 1. Washington, D.C.: World Bank.

47.Wu, F., Mahajan, V., and Balasubramanian, S. (2003). An analysis of e-business adoption and its impact on business performance. Journal of the Academy of Marketing science, 31(4), 425-447.

48.Ziewitz, M. and Brown, I. (2014). A Prehistory of Internet Governance. I. Brown, I., (ed.) Research Handbook on Governance of the Internet, Cheltenham: Edward Elgar, pp. 3-26. 